DOI https://doi.org/10.18551/rjoas.2017-01.29

\title{
JAMBI LOCAL RICE VARIETY (ORYZA SATIVA L.) ADAPTATION SCREENING AGAINST DROUGHT STRESS DURING SEEDING PROCESS
}

\author{
Aryunis $^{1,2 *}$, Agus Suryanto ${ }^{3}$, Nur Basuki ${ }^{3}$, Bambang Guritno ${ }^{3}$ \\ ${ }^{1}$ Doctoral Degree Program in Agriculture, Faculty of Agriculture, \\ University of Brawijaya, Indonesia \\ ${ }^{2}$ Agro-technology Program, Faculty of Agriculture, University of Jambi, Indonesia \\ ${ }^{3}$ Agriculture Cultivation Program, Faculty of Agriculture, University of Brawijaya, Indonesia
}

*E-mail: aryunis oeddin@yahoo.com

\begin{abstract}
Screening Jambi local rice (Oryza sativa L.) adaptive to drought stress at seeding stage, aimed to obtain Jambi local rice variety which are adaptive to extreme drought conditions to be able to cope with uncertain rainfall rate as a result of climate change, a source of enrichment for the germplasm assembly and improving new varieties that can cope with global climate change in increasing rice produce. The research was conducted in 2013 at the Balai Besar Penelitian Padi, Kebun Percobaan Padi Muara Bogor (Rice Research Institute, Rice Experimental Farm Muara Bogor). Materials examined were Jambi local rice varieties based on exploration results in 2004, 2009 and 2013 conducted in Jambi province. Drought screening was performed on seedling at 14 and 21 days after sowing (DAS) with soil moisture level under $20 \%$ to 105 Jambi local rice varieties and 2 control varieties. The control varieties are Salumpikit (drought tolerant) and IR20 (drought sensitive) obtained from Balai Besar Penelitian Padi Kebun Percobaan Bogor. This research is selection process conducted on Jambi local rice varieties against drought stress performed during seeding phase. Observations were conducted on survival rate percentage (survival). The results exhibits 26 out of 105 local rice varieties were evaluated as drought resistant at soil moisture level $\pm 17 \%, 14$ varieties are drought resistant 14 and 21 DAS, 10 varieties resistant to drought at 14 DAS and 2 drought resistant varieties at 21 DAS.
\end{abstract}

\section{KEY WORDS}

Jambi local rice (landraces), adapt, drought stress, seeding stage.

Uncertainty in rainfall distribution both at present and in the years to come would worsen as a result of global climate change. This would mean dry conditions occurring in the middle of rainy season capable of damaging plant growth, followed by flood at the end of rainy season which would affect rice yields (Kawasaki, 2010). Uncertainties associated particularly concerning rainfall patterns due to climate change. It is expected to be difficult in anticipating drought effect (Anonymous, 2011) .To overcome irregularities in rainfall patterns, rice varieties capable of adapting to global climate change and resistant to drought is required. It would encourage a positive impact on rice yields (Kawasaki, 2010).

Jambi Province possesses rice planting area 75.100 ha (BPS, 1996) with a number of local rice varieties. Local rice has been grown for generations and has adapted well to its environment. Local rice cultivars are valuable asset should they are managed appropriately (Siwi, and Kartowinoto, 1989). Diversity of local rice cultivars in Jambi is quite high, but there is no known variety possessing drought resistant characteristic. Information regarding the diversity of Jambi local rice drought resistance in growth phases, genetic and germplasm collections is not yet available. Therefore it is necessary to identify and evaluate rice variety and its germplasm to obtain variety possessing adaptive and drought resistant traits.

Managing rice plant genetic resources included efforts to preserve, secure, and utilizing genetic diversity as optimal as possible to render them useful. It is done both for present and future generation. Cultivated plants species possess valuable genetic resources for crop improvement program (Oldfield, 1989). 
Operational measures in managing genetic resources are: 1) exploration, inventory, and identification of genetic resources, 2) collecting in ex situ and in situ manner, 3) passportization and documentation, 4) evaluation, characterization, and cataloging, 5) usage, selection, hybridization, and varieties assembly, 6) conservation and rejuvenating, and 7) material exchange, protection, and commercialization.

Rice plants cultivation in Jambi province is mostly conducted in a specific cultivation environment (agro-ecology specific) known as tidal rice cultivation, swamp rice cultivation, gogo rice cultivation and rain-fed rice cultivation. Most of these are marginal lands. Varieties grown in general are local varieties grown and adapted to suit environmental conditions, and has been grown for generations.

Exploration is activity of seeking, collecting and researching varieties in certain areas. Aryunis et al. (2004 and 2009), Aryunis (2013) has explored local rice in rice tidal agroecosystem, rice rain-fed field, swamp / lowland rice field, payo rice, gogo rice and irrigated rice field. The exploration results found 105 local rice varieties from Jambi. Local rice has high adaptability to each agro-ecosystem, but there is no known drought resistance trait in them. Therefore this research aims to obtain local rice varieties in Jambi which is resistant to drought in seedbed phase.

\section{MATERIAL AND METHODS}

Research Material. Materials used in this study is local rice varieties from Jambi, based on exploratory research result of Aryunis et al., (2004 and 2009) and Aryunis (2013) in agroecosystem wetlands and dry land in Jambi. There are 105 varieties and used two introduced varieties as control variety which are Salumpikit (drought tolerant) and IR20 (drought sensitive), varieties obtained from Kebun Percobaan Muara Balai Besar Penelitian Padi (Muara Rice Research Institute Experimental Farm) in Bogor, Urea, $\mathrm{KCl}, \mathrm{SP} 36$, and rice field study site.

Tools used in this study is greenhouse utilized in drought screening test. Plastic tubs for seedling media $40 \mathrm{~cm} \times 25 \mathrm{~cm} \times 14 \mathrm{~cm}$. Oven, Lux Hitester Hioki 3423 brand made in Japan, petridis cup, aluminum saucer and oil absorbent paper.

Research Time and Place. The experiment was conducted at Greenhouse of Kebun Percobaan Muara Balai Besar Penelitian Padi Bogor. This study was conducted from January to June 2013.

Research Method. Jambi local rice taken from exploration results are evaluated (screening) for determining survival rate during and after drought stress test. Screening was done at the seedling stage, at 14 and 21 DAS (days after sowing). Seeds sown in plastic tubs filled with field soil and created conditions according to standard operating procedures of rice cultivation on wet seedbed. Germinated seed in petridisc cup were sowed in seedling tub as much as 20 seeds (sprouts) for each variety in a test. Each tub possess 10 lines, two lines for drought tolerant and drought sensitive varieties. Treatment implemenation on drought seedbed media was carried out in accordance to seedling age by removing water on each plastic tub until water on media's surface runs out. The tubs are left to dry until a third of drought sensitive variety (IR20) leaves withered. After drought period was finished, seedbed soil samples were taken and their water content was analyzed .Recovery phase was conducted afterwards by providing water according to wet seedbed water requirements. Data were collected for grown seeds (vigor) and freshness criteria.

Data Analysis. To determine the treatment effect towards drought survival rate and seed height, researcher used descriptive analysis presented in tabular form.

Variable Observation. Observations on the percentage of survival (survival) is done 21 days after recovery (DAR) to seed which grew perfectly and retain freshness. Survival percentage is calculated as: local variety resistant seed percentage ( $T$ ) divided by the number of seeds sown. The result of the survival rate calculation is exhibitted as follows:

Number of surviving seed from tested local variety $x 100 \%$ Number of sown seed 

(Table 1).

Drought tolerance scoring is based on a standard evaluation system IRRI (1988)

Table 1 - Rice plant tolerance scoring against drought after recovery (IRRI, 1988)

\begin{tabular}{|c|l|l|}
\hline Scale & \multicolumn{1}{|c|}{ Post-recovery scoring } & \multicolumn{1}{c|}{ Drought tolerance level } \\
\hline 1 & $90-100 \%$ recovered seeds & Very strong (seeds grow very quickly) \\
\hline 3 & $70-89 \%$ recovered seeds & Strong (seeds grow quickly) \\
\hline 5 & $40-69 \%$ recovered seeds & Normal \\
\hline 7 & $20-39 \%$ recovered seeds & Weak (Small seeds) \\
\hline 9 & $0-19 \%$ recovered seeds & Very weak (Small seeds and yellow leaves) \\
\hline
\end{tabular}

\section{FINDINGS AND DISCUSSION}

The results of screening 105 local rice varieties in Jambi conducted on droughtresistant control variety and IR 20 drought-sensitive controls variety against drought stress in seedling 14 DAS. It exhibits Jambi local rice survival rate which ranges from 0 to $90 \%$ (data not published). Drought at the 21 DAS exhibits seedling survival percentage which ranges from 0 to $90 \%$ (data not published). Selected local rice varieties showed better response compared to Salumpikit.

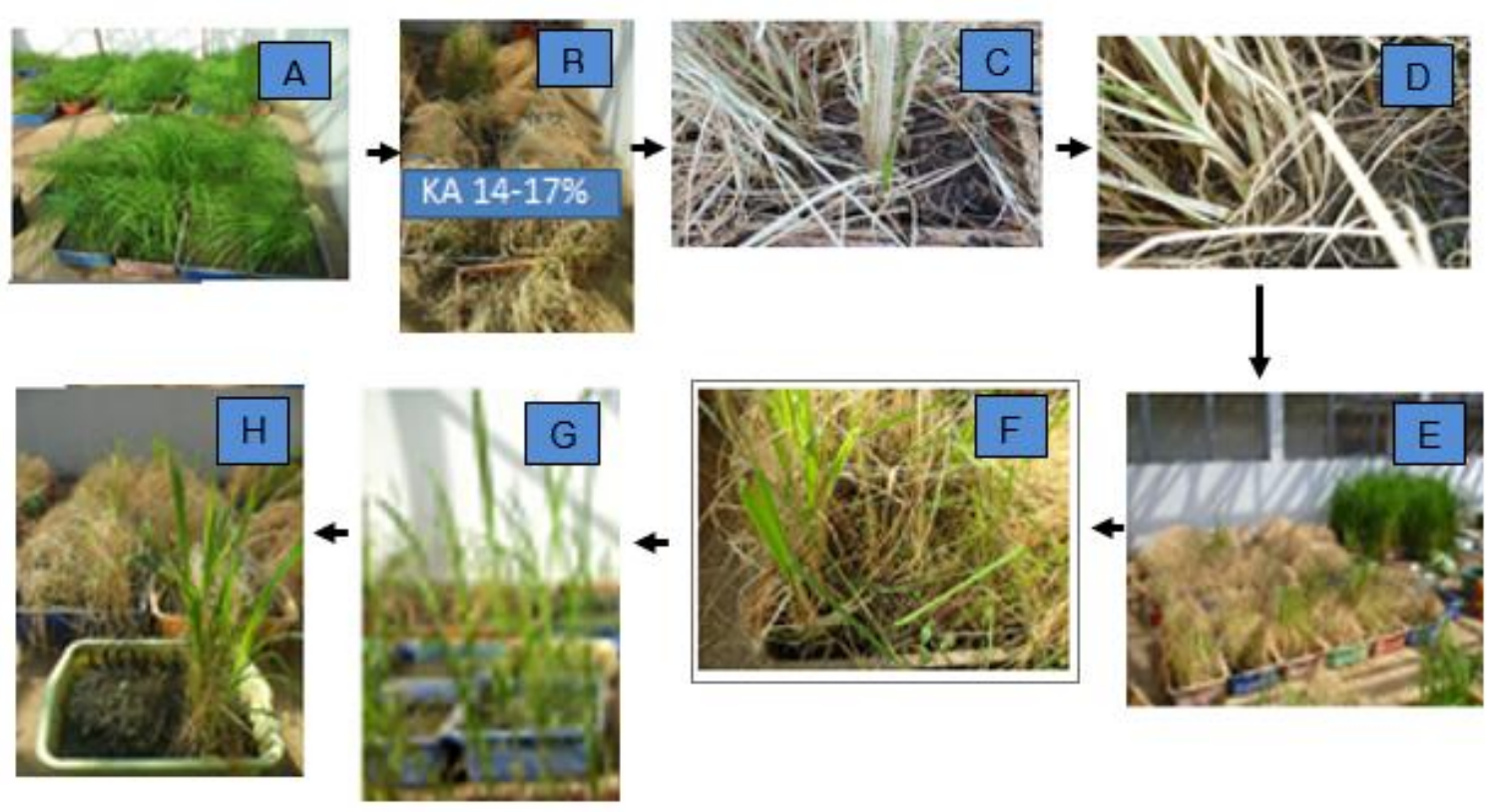

Figure 1 - Screening phase of Jambi local rice variety adaptation to drought stress up to $14-17 \%$ water soil content (under permanent wilting point) applied to seeding bed at Rumah Kaca Balai Besar Padi or Balai Besar Padi Greenhouse Muara Bogor Experimental Garden at 2013:
A. Drought stress process starts in seeding media at $100 \%$ water content.
B. Ending drought stress process after water content reaches $14-17 \%$ and initiated recovery process.
C. Seeds started to recover.
D. Seedling leaves started to grow.
E. Diffierentiates seeds with drought stress applied and non-applied.
F. Seed leaves started to grow normally.
G. Seeds grow normally, calculated grown seed's survival rate \% at 21 days after seeding.
$\mathrm{H}$. Variety possessing highest survival rate percentage $(90 \%)$.

There were 11 local varieties selected from 105 Jambi rice variety and 2 control varieties (Salumpikit dan IR20). They possess survival stability after exposed to drought stress at 14 and 21 DAS. Forementioned 11 varieties are as follows:Padan wangi $60 \%$ and $20 \%$, Iwan $70 \%$ and $25 \%$, Putih Rendah $70 \%$ and $90 \%$, Karya $30 \%$ and $30 \%$, Karya Rendah $80 \%$ and $40 \%$, Solok Kuning $55 \%$ and $70 \%$, Kusut tidak berbulu $30 \%$ and $35 \%$, Solok Putih 
coklat di ujung $20 \%$ and $15 \%$, Solok putih Kuning 50\% and 45\%, Payo $45 \%$ and $30 \%$, Kurai Kusut $90 \%$ and $40 \%$, Salumpikit $45 \%$ and $25 \%$ and IR $2015 \%$ and $25 \%$. Jambi local rice variety that survived drought stress applied at 14 DAS and not surviving drought stress at 21 DAS is as follows: Kuatik Kuning $55 \%$, Padi putih $45 \%$, Payo manis $45 \%$, Jelatik $75 \%$, Layap 70\%, Layap Patah Daun 50\%, Jelatik Batang Merah 45\%, Sirendah pisang berbulu 55\%, Sirendah pisang tidak berbulu $60 \%$ and Surian Kuning (beras putih) $70 \%$. There are two (2) varieties that survived drought stress applied on 21 DAS as opposed to 14 DAS. Fore mentioned varieties are Seni $25 \%$ and Ungul super $25 \%$.

Table 2 - Screening result of Jambi local rice variety survival rate after drought stress applied at 14 and 21 DAS

\begin{tabular}{|c|c|c|c|c|}
\hline \multirow[t]{2}{*}{ No. } & \multirow{2}{*}{$\begin{array}{l}\text { No. Variety } \\
\text { Accession }\end{array}$} & \multirow{2}{*}{ Variety Name } & Drought at 14 DAS & Drought at $21 \mathrm{DAS}$ \\
\hline & & & \%Survival & $\%$ Survival \\
\hline 1 & 1 & Padan wangi & 60 & 20 \\
\hline 2 & 4 & Kuatik Kuning & 55 & - \\
\hline 3 & 5 & Padi Putih & 45 & - \\
\hline 4 & 13 & Payo manis & 45 & - \\
\hline 5 & 18 & Iwan & 70 & 25 \\
\hline 6 & 19 & Rendah putih & 70 & 90 \\
\hline 7 & 23 & Karya & 30 & 30 \\
\hline 8 & $24 B$ & Ceko tidak berbulu & 15 & 15 \\
\hline 9 & 26 & Lembu & 50 & 25 \\
\hline 10 & 27 & Conde & 55 & 40 \\
\hline 11 & 28 & Unggul Super & - & 25 \\
\hline 12 & 29 & Seni & - & 25 \\
\hline 13 & 34 & Jelatik & 75 & - \\
\hline 14 & 35 & Layap & 70 & - \\
\hline 15 & 36 & Layap Patah Daun & 50 & - \\
\hline 16 & 37 & Karya rendah & 80 & 40 \\
\hline 17 & 38 & Jelatik batang merah & 45 & - \\
\hline 18 & $47 \mathrm{~A}$ & Sirendah pisang berbulu & 55 & - \\
\hline 19 & 47B & Sirendah pisang tidak berbulu & 60 & - \\
\hline 20 & 48 & Solok kuning & 55 & 70 \\
\hline 21 & $49 B$ & Kusut tidak berbulu & 30 & 35 \\
\hline 22 & $50 \mathrm{~B}$ & Surian kuning (beras putih) & 70 & - \\
\hline 23 & $51 \mathrm{~A}$ & Solok Putih coklat di ujung & 75 & 15 \\
\hline 24 & $51 \mathrm{~B}$ & Solok putih Kuning & 50 & 45 \\
\hline 25 & 52 & Payo & 45 & 30 \\
\hline 26 & 88 & Kurai kusut & 90 & 40 \\
\hline 27 & $\begin{array}{c}\text { Resistant } \\
\text { Control Variety }\end{array}$ & Salumpikit & 45 & 25 \\
\hline 28 & $\begin{array}{c}\text { Sensitive } \\
\text { Control Variety }\end{array}$ & IR 20 & 15 & 25 \\
\hline
\end{tabular}

The research results also exhibit some Jambi local rice variety possessing higher survival rate percentage compared to drought resistant control variety (Salumpikit) after drought stress applied at 14 DAS. Forementioned varieties are:Padan wangi, Kuatik Kuning, Iwan, Putih Rendah, Lembu, Conde, Jelatik, Layap, Layap Patah Daun, Karya Rendah, Sirendah pisang berbulu, Sirendah pisang tidak berbulu, Solok Kuning, Surian Kuning (beras putih), Solok Putih coklat di ujung, Solok putih Kuning and Kurai Kusut. On the other hand, varieties that possess higher survival rate percentage compared to Salumpikit control variety after drought stress at 21 Das are: Putih Rendah, Karya, Conde, Karya Rendah, Solok Kuning, Kusut tidak berbulu, Solok putih Kuning, Payo and Kurai Kusut (Table 1). Therefore this research found a number of Jambi local rice varieties possessing more stable drought resistant trait compared to control variety. The varieties are as follows:Putih Rendah, Conde, Karya Rendah, Solok Kuning, Solok putih Kuning, and Kurai Kusut. 


\section{DISCUSSION OF RESULTS}

The research results exhibit Jambi local rice Padan wangi, Iwan, Putih Rendah, Karya, Ceko tidak berbulu, Lembu, Conde, Karya Rendah, Solok Kuning, Kusut tidak berbulu, Solok Putih coklat di ujung, Solok putih Kuning, Payo, Kurai Kusut, Salumpikit and IR 20 possess survival capability when exposed to drought stress at 14 dan 21 DAS. Nevertheless, drought resistant rice variety which possess higher survival rate compared to drought sensitive control IR 20 variety are Putih Rendah, Conde, Karya Rendah, Solok Kuning, Solok putih Kuning, Payo and Kurai Kusut. Every rice seed from Jambi local variety and control varieties (drought resistant and drought sensitive variety) that managed to grow after drought stress recovery phase are included in normal growth category (Figure 1). Research result exhibits difference in survival capability possessed by same variety against drought stress applied at different day after seeding (DAS). It is considered if the survivability aspect of a variety is not always expressed during drought stress. According to (Zulkarnain et al., 2009a different mechanism appears to protect itself at every stage of water loss occurred during drought. Survival strategies during the initial dehydration would be to avoid protein unfolding and limiting membrane disruption with preferential hydration. After further water loss on cell hydration, sugar molecules ought to replace water in the hydrogen sites to preserve protein original structure and distance between phospholipids. This causes plants capable to survive in drought conditions.

\section{CONCLUSION}

Jambi local rice variety such as Putih Rendah, Conde, Karya Rendah, Solok Kuning, Solok putih Kuning, and Kurai Kusut were identified as drought adaptive are varieties possessing similar or higher survival rate percentage compared to drought resistant control variety conducted at 14 and 21 DAS. From rice plant improvement perspective, local rice varietyis a valuable asset as the source of germplasm to broaden the source of genetic diversity for drought-resistant properties.

\section{ACKNOWLEDGEMENTS}

The authors would like to extend their gratitude to Dr. Fitry Tafzi, S.T.P., M.Si, for her aid in selecting Jambi local rice variety based on exploration result which is done meticulously to ensure homogeny plant material. The authors also extend their gratitude to the Director of Qualification of Human Resources, General Directorate of Science and Technology Resources, Ministry of Research, Technology, and Higher Education, Republic of Indonesia for granting BPPDN (Beasiswa Program Pascasarjana Dalam Negeri or Domestic Post-Graduate Program Grant) to the authors.

\section{REFERENCES}

1. The impact of climate change on rice production (2011). Agricultural Bacillen Projection. Economic Research. USDA.

2. Aryunis, Esrita, and Tafzi, F. (2004). Eksplorasi Padi Lokal Pasang Surut dengan Rasa Nasi Enak di Kabupaten Tanjung Jabung Barat Provinsi Jambi. Unpublished Research Report, Universitas Jambi.

3. Aryunis. (2009). Eksplorasi dan identifikasi padi lokal asal Jambi berdasarkan Agroekologi dan perbanyakan dalam upaya pelestarian plasmanutfah. Unpublished Research Report, Universitas Jambi.

4. Aryunis. 2013. Ekplorasi pada daerah rawan banjir di Kabupaten Muara Jambi Provinsi Jambi. Unpublished Research Report, Universitas Jambi.

5. Biro Pusat Statistik. 1996. Jambi Dalam Angka. Jambi Province.

6. IRR1. 1988. Standard evaluation system for rice. IRRI, Manila, Philippines. 
7. Kawasaki, J. (2010). Thailand's rice farmers adapt to climate change. OurWorld 2.0 Book university Crop and natural resource management for climate-ready rice in unfavorable environments: coping with adverse conditions and creating opportunities. IRRI Limited Proceding Series No.16.

8. Oldfield, M.L. (1989). The Value of Conserving Resources. Sinauer, Sunderland.

9. Siwi, B.H. and Kartowinoto, S. (1989). Plasma Nutfah Padi dalam Padi Buku 2. Pusat Penelitian dan Pengembangan Tanaman Pangan, Bogor.

10. Zulkarnain, W.M, Ismail, M.R., Ashrafuzzaman, Saud, M.H., and Haroun, I.C. (2009). Growth, phsyological, and biochemical responses of Malaysia rice cultivars to water stress. Pertanika J. Trop. Agric. Sci. 32(2):323-333. 